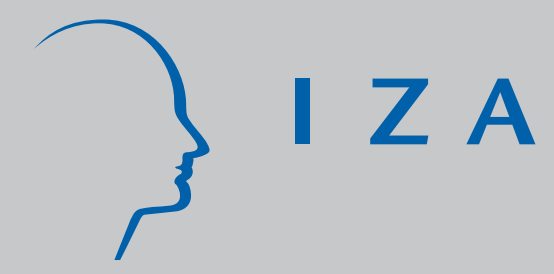

IZA DP No. 3978

Gender Pay Gap and Quantile Regression in European Families

Catia Nicodemo

J anuary 2009 


\title{
Gender Pay Gap and Quantile Regression in European Families
}

\author{
Catia Nicodemo \\ Universitat Autónoma de Barcelona \\ and IZA
}

Discussion Paper No. 3978

January 2009

IZA

P.O. Box 7240

53072 Bonn

Germany

Phone: +49-228-3894-0

Fax: +49-228-3894-180

E-mail: iza@iza.org

Any opinions expressed here are those of the author(s) and not those of IZA. Research published in this series may include views on policy, but the institute itself takes no institutional policy positions.

The Institute for the Study of Labor (IZA) in Bonn is a local and virtual international research center and a place of communication between science, politics and business. IZA is an independent nonprofit organization supported by Deutsche Post Foundation. The center is associated with the University of Bonn and offers a stimulating research environment through its international network, workshops and conferences, data service, project support, research visits and doctoral program. IZA engages in (i) original and internationally competitive research in all fields of labor economics, (ii) development of policy concepts, and (iii) dissemination of research results and concepts to the interested public.

IZA Discussion Papers often represent preliminary work and are circulated to encourage discussion. Citation of such a paper should account for its provisional character. A revised version may be available directly from the author. 


\section{ABSTRACT}

\section{Gender Pay Gap and Quantile Regression in European Families*}

In this paper we analyze the trend of the gender gap between wives and husbands for Mediterranean countries with a strong family tradition, using data from the European Household Panel (ECHP) of 2001 and the European Survey on Income and Living Conditions (EU-SILC) of 2006. In general, wives and husbands, when married, have the same characteristics but wives suffer from two types of discrimination with respect to husbands: a lower wage for the same work and a primary responsibility for children. This paper uses quantile regression and counterfactual decomposition methods to investigate whether a glass ceiling exists or if instead a sticky floor is more prevalent among European families over time (2001 and 2006). We correct for selectivity the unconditional wage distribution of married women and we show that the wage gap decomposition is different if we ignore self-selection. We find that the wage gap is positive in each country, and the greater part of it is composed of a discrimination effect, while the characteristics effect is small. In Mediterranean countries, wives suffer from the sticky floor effect, i.e. the gender gap is bigger at the bottom of distribution, while we can observe that the glass ceiling effect decreased in most countries in 2006.

JEL Classification: J16, J31, C2, C3

Keywords: gender pay gap, selection, quantile regression, counterfactual decomposition

Corresponding author:

Catia Nicodemo

Universitat Autonoma de Barcelona

Department of Applied Economics

Campus Bellaterra

08193 Bellaterra (Cerdanyola)

Spain

E-mail: catia.nicodemo@upf.edu

\footnotetext{
* I'm grateful to Robert Waldman, Jaume García, Sergi Jiménez-Martín and Wolf Dieter Heinbach for their help and suggestions. All errors are mine.
} 


\section{Introduction}

The gender pay gap refers to the differences between the wages earned by women and men. It is an evident and documented fact that men earn higher wages than women, even after checking both for observable characteristics related to their productivity and the overall wage structure (see, e.g., Blau and Kahn, 2000).

Reducing the gender pay gap is an important topic on the European political agenda. In 2003 the member countries formulated the plan to achieve by 2010 a substantial reduction in the gender pay gap in each Member State (Council Decision 2003 L197/20). The persistence of the gender pay gap is the result of direct discrimination against women and structural inequalities, such as segregation in sectors, occupations, access to education and training, biased evaluation and pay systems, etc. A large amount of empirical research tends to explain the trend of the wage gap in Europe, but few studies concentrate on the gap that exists in a family. If we look at Figure 1 we find that the unadjusted gender gap has increased in the last few years in Spain, Italy and Portugal and decreased in Greece and France, but with respect to 1995 it has increased in all Mediterranean countries.

There are many papers concerning the evolution over time of wage inequality that take into consideration the different aspects of the labor market, such as education, public or private sector, etc., but of investigation the degree to which the gender gap in a family may vary across wages distribution, and why, is very scarce.

De la Rica, Dolado and Llorens (2005) using 1999 data for Spain found that the gender wage gap is expanding over the wage distribution only for the group with college/tertiary education. For less educated groups, the gender wage gap is wider at the bottom than the top. Thus, in Spain for the better educated there is a glass ceiling while for the less educated there is not. Using a different decomposition methodology in the quantile regressions framework and Spanish data for 1995, del Rio, Gradin and Canto (2005) obtain similar results to de la Rica et. al.

Albrecht, Bjorklund and Vroman (2003), analyzing Swedish data relating to 1998 , show that the gender wage gap is increasing throughout the wage distribution and accelerating at the top, and they interpret this as evidence of a glass ceiling in Sweden.

The increasing labor market participation of women, changing family forms and family responsibility, has made the compromise between work and family one of the major topics of the European social agenda. Countries have different social and labor market policies, sometimes focusing on more flexible working hours, occasionally encouraging the supply of public and private services and sometimes with policies to increase an equal distribution of earnings. The discrimination in a family comes from two sources: family responsibilities, such as looking after children (see table13), and lower wages 
Figure 1: Gender pay gap in unadjusted form

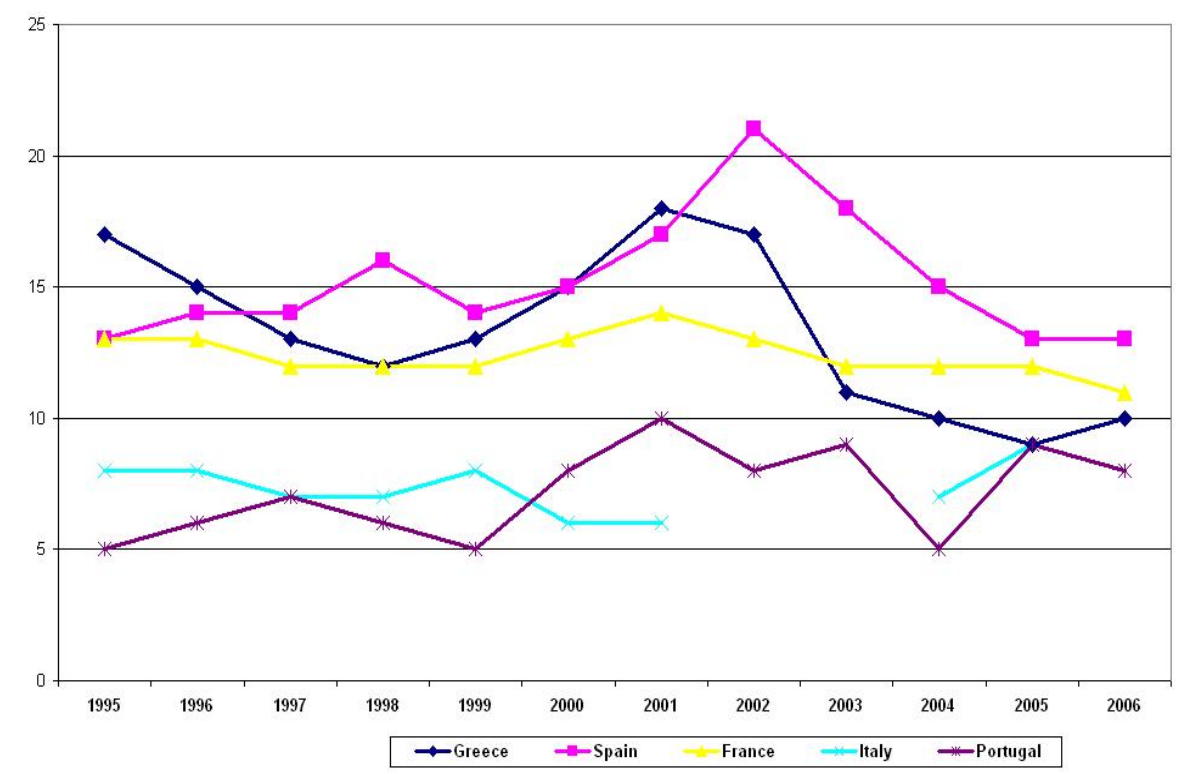

Data source: EUROSTAT Gender pay gap is given as the difference between average gross hourly earnings of male paid employees and of female paid employees as a percentage of average gross hourly earnings of male

paid employees. The population consists of all paid employees aged 16-64 that are at work more than 15 hours per week.Data source: EUROSTAT Gender pay gap is given as the difference between average gross hourly earnings of male paid employees and of female paid employees as a percentage of average gross hourly earnings of male paid employees. The population consists of all paid employees aged 16-64 that are at work more than 15 hours per week.

with respect to the husband's even with the same characteristics; at times, this gap in earnings creates conflicts in the family and psychological problems for women.

The aim of this paper is to investigate the gender gap between husbands and wives and its evolution from 2001 to 2006, using data from the European Community Household Panel and the European Survey on Income and Living Conditions.

We explain why countries with poor policies for child-care, flexibility of work etc., are more unequal. Normally these countries belong to the Mediterranean area, with a strong tradition in the family, and most of them suffer from the sticky floor effect, i.e. the gender pay gap is bigger at the bottom of the wage distribution.

To estimate the difference in earnings in an Mediterranean family we consider the standard methodology such as the Blinder-Oaxaca (1973) decompositions and the quantile regression method using a Machado-Mata (2005) and Melly's decomposition (2006). However, a significant part of 
the women in the sample do not work, so if unobservable characteristics in the wage and in the participation equations are correlated so we need to take into account the sample selection that females' wages suffer, and use a proper treatment. Correcting for sample selection is also essential if we want to compare the gender gap between countries.

This chapter is structured in several sections. The first is a brief introduction about the data we use for our research. After we show the unadjusted gender gap in Europe over time, the adjusted gender gap and the estimation methods of the wage equation with the Oaxaca-Blinder decomposition. At end we present the method of Melly's quantile regression and counterfactual distribution, and the empirical evidence in five European countries.

\section{Data}

The data analyzed in this work come from a survey by the European Community Household Panel (ECHP) and the EU-SILC (European Income and Living Conditions).

The ECHP is a multi-country annual longitudinal survey of collected data since $1994^{1}$ in 15 European Union Member States under Eurostat (Statistical Office of the European Communities) coordination.

The data set covers approximately 130,000 individuals from 60,000 households in the fifteen countries which were EU members in 2000, reflecting population changes over time through a continuous evolution of the sample. The panel data cover a wide range of subjects such as demographics, labor force behavior, income, health, education and training, housing, poverty and social exclusion, etc.

The survey is structured in the form of annual interviews with a particular representative sample of household members in each country. Interviews were conducted following a standardized questionnaire, although each country could modify the questionnaire's wording to some extent, to reflect its own institutional arrangements.

The sample is constructed as an unbalanced panel of all women between the ages of 25 and 55 years, who are married with or without children, matched with their husbands who are presently employed or out of the labor force. We excluded self-employed and not economically active people (pensioners, the military, etc). The size of this sample varies across countries.

The European Union Statistics on Income and Living Conditions (EUSILC) is an instrument aiming at collecting timely and comparable cross-

\footnotetext{
${ }^{1}$ Belgium, Germany, the Netherlands, the U.K., Denmark, France, Greece, Ireland, Portugal, Italy and Spain started in 1994 (wave 1), Austria joined in 1995 (wave 2), Finland joined in 1996 (wave 3).
} 
sectional and longitudinal multidimensional microdata on income, poverty, social exclusion and living conditions.

The EU-SILC aims to provide two types of data:

- Cross-sectional data pertaining to a given time or a certain time period with variables on income, poverty, social exclusion and other living conditions.

- Longitudinal data pertaining to individual-level changes over time, observed periodically, typically over a four year period.

Social exclusion and housing condition information is collected at household level while labor, education and health information is obtained for people aged 16 and over. The core of the instrument, income at very detailed component level, is mainly collected at personal level but a few components are included in the household part of the SILC.

The variables refer to the personal characteristics of individuals (age, work experience, education) and characteristics of the household family. We take into consideration all married couples who have a positive wage and work for at least 8 hours per week to reduce the measurement error connected with the wage measure. All income variables are deflated with CPI (Consumer Price Index) so a comparison among years is possible.

Table 1 shows the participation rate of husbands and wives, calculated on the last wave of the $\operatorname{ECHP(2001)~and~the~EU-SILC~data~in~2006,~considering~}$ the husbands and wives who work part-time or full-time. In these samples the female participation rate is very different with respect to husbands. It increased in 2006 around 5\%-7\% in all countries, except in Portugal where it remained the same. France and Portugal are the countries with a higher employment rate compared to other Mediterranean countries.

We can conclude that the Lisbon target, where the European Union had fixed that the women of working age who participate in the labor market in 2010, have to be more that $60 \%$, is well above that of Italy, Spain and Greece.

Table 1: Participation rate of husbands and wives in the ECHP and EU-SILC

\begin{tabular}{r|rr|rr}
\hline & \multicolumn{2}{|c|}{ EU-SILC } & \multicolumn{2}{c}{ ECHP } \\
\hline \hline Country & Wives & Husbands & Wives & Husbands \\
France & 69.51 & 88.53 & 64.88 & 87.43 \\
Italy & 51.21 & 87.28 & 44.24 & 82.02 \\
Portugal & 69.53 & 88.47 & 69.34 & 90.35 \\
Spain & 51.85 & 88.32 & 45.93 & 87.52 \\
Greece & 52.72 & 89.31 & 41.34 & 83.26 \\
\hline \hline \multicolumn{2}{r|}{ Source: ECHP 2001 and EU-SILC 2006, husband and wife of working age, who }
\end{tabular}




\section{The unadjusted gender pay gap}

We first analyze the raw or unadjusted gender gap across Europe in the years 1994 and 2001 using the ECHP data set. The earnings measure for the raw gap is the average of the gross deflated hourly wage. Wages in the ECHP are not directly observed, but obtained by dividing the current monthly total gross earnings by the total number of hours worked per week, multiplied by 4.3 .

Table 2 shows the average gender gap in European countries in 1994 and 2001. The absolute gender gap, calculated as the difference between husband minus wife's average gross hourly wage, increased in 2001 for France, the U.K, Denmark, Portugal, Greece, Spain, Belgium, Finland and Austria, while it decreased for the rest of the countries.

In Figure 2, the relative wage gap is presented, calculated as the ratio between the absolute wage gap and the average male wage rate. The relative wage gap in 2001 between husbands and wives in EU varied between $6 \%$ in Italy and $28 \%$ in the U.K. The largest reduction between the year 1994 and 2001 is observed in Ireland (-8\%) and Italy (-7\%), while the U.K., France, Belgium, Finland and the Netherlands presented a reduction of approximately $-2 \%$ in 2001. In Spain, Portugal and Greece we observe an increase of around $4 \%$ in the gender gap in 2001, while in Denmark, Austria and Germany the gender gap increased about $2 \%$ in 2001. This work is in accordance with Sissoko et al (2006) and Beblo et al (2003) studies.

In Figure 3 we report the average hourly wage for husbands and wives, the absolute wage gap and the relative wage gap calculated on the sample EU-SILC in 2006 for Mediterranean countries. The relative wage gap is high in Spain and France, around 12\% and 18\% respectively. 
Table 2: Unadjusted gender gap in European countries, 1994-2001

\begin{tabular}{|c|c|c|c|c|c|c|}
\hline \multirow[t]{2}{*}{ Country } & \multicolumn{3}{|c|}{2001} & \multicolumn{3}{|c|}{1994} \\
\hline & Male & Female & $\begin{array}{l}\text { Absolute } \\
\text { wage gap }\end{array}$ & Male & Female & $\begin{array}{l}\text { Absolute } \\
\text { wage gap }\end{array}$ \\
\hline Germany & 23.1 & 17.49 & 5.61 & 22.59 & 17.31 & 5.28 \\
\hline Denmark & 129.95 & 109.69 & 20.26 & 112.42 & 97.68 & 14.74 \\
\hline The Netherlands & 25.41 & 19.32 & 6.09 & 29.36 & 21.51 & 7.85 \\
\hline Belgium & 520.31 & 440.94 & 79.37 & 457.86 & 383.88 & 73.98 \\
\hline France & 74.58 & 60.89 & 13.69 & 76.25 & 61.36 & 14.89 \\
\hline U.K. & 9.33 & 7 & 2.33 & 7.66 & 5.46 & 2.2 \\
\hline Ireland & 10.42 & 8.7 & 1.72 & 8.51 & 6.44 & 2.07 \\
\hline Italy & 15121.37 & 14268.14 & 853.23 & 15100.26 & 1398.27 & 13701.99 \\
\hline Greece & 1997.64 & 1641.29 & 356.35 & 1358.76 & 1145.87 & 212.89 \\
\hline Spain & 1267.47 & 1057.39 & 210.08 & 1094.64 & 978.6 & 116.04 \\
\hline Portugal & 774.32 & 662.55 & 111.77 & 681.05 & 604.26 & 76.79 \\
\hline Austria & 139.22 & 104.86 & 34.36 & 151.6 & 114.65 & 36.95 \\
\hline Finland & 70.67 & 55.81 & 14.86 & 66.92 & 51.89 & 15.03 \\
\hline
\end{tabular}

at least 8 hours per week. For Austria has used the wave 1995 and Finland has used wave

1996 
Figure 2: Relative raw wage gap in European countries: ECHP 1994-2001

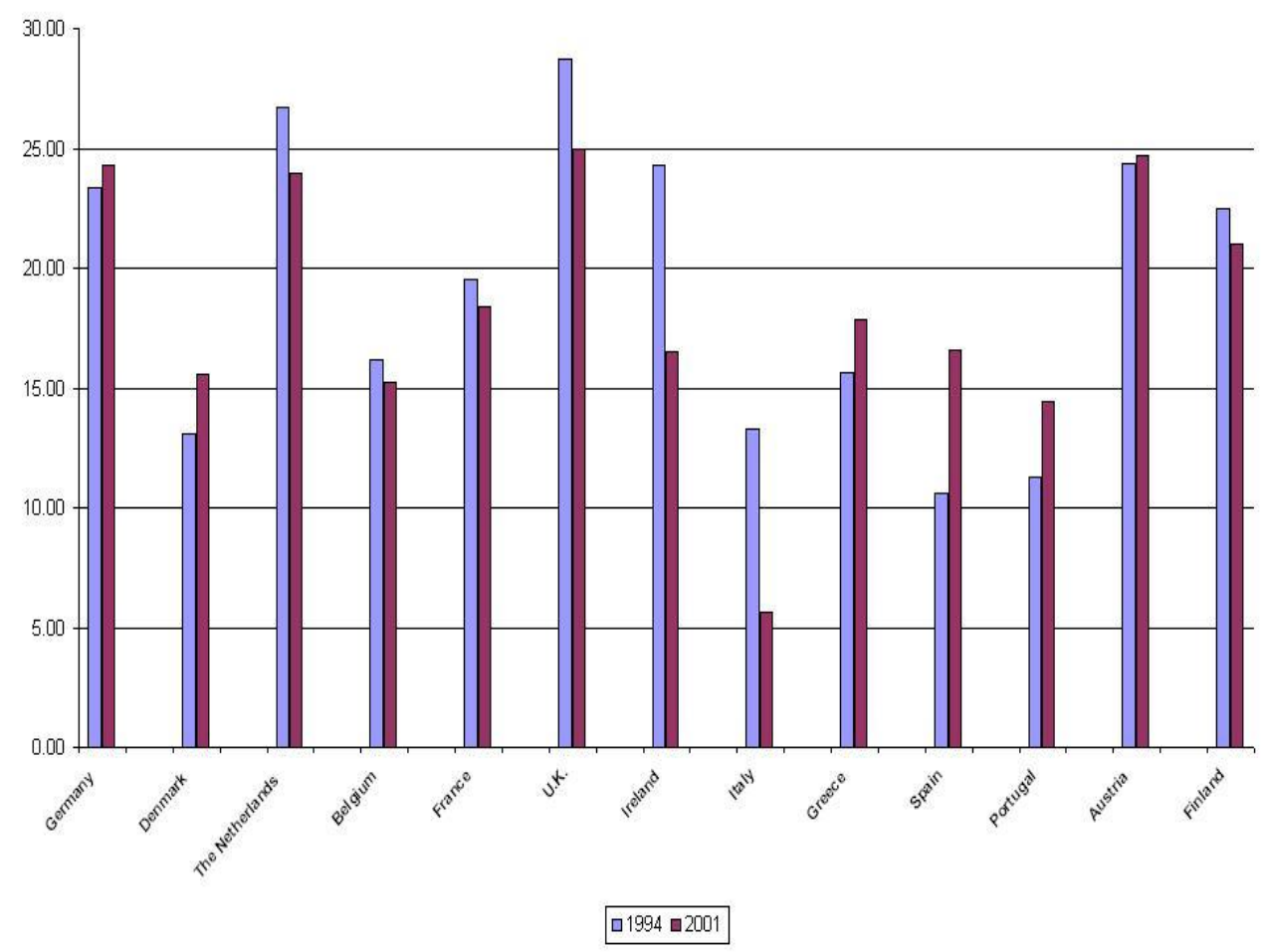

Data source: ECHP average hourly wage in local currency, husband and wife in working

age, who are employed at least 8 hours per week. For Austria has used the wave 1995 and

Finland has used wave 1996 
Figure 3: Relative raw wage gap in European countries: EU-SILC 2006

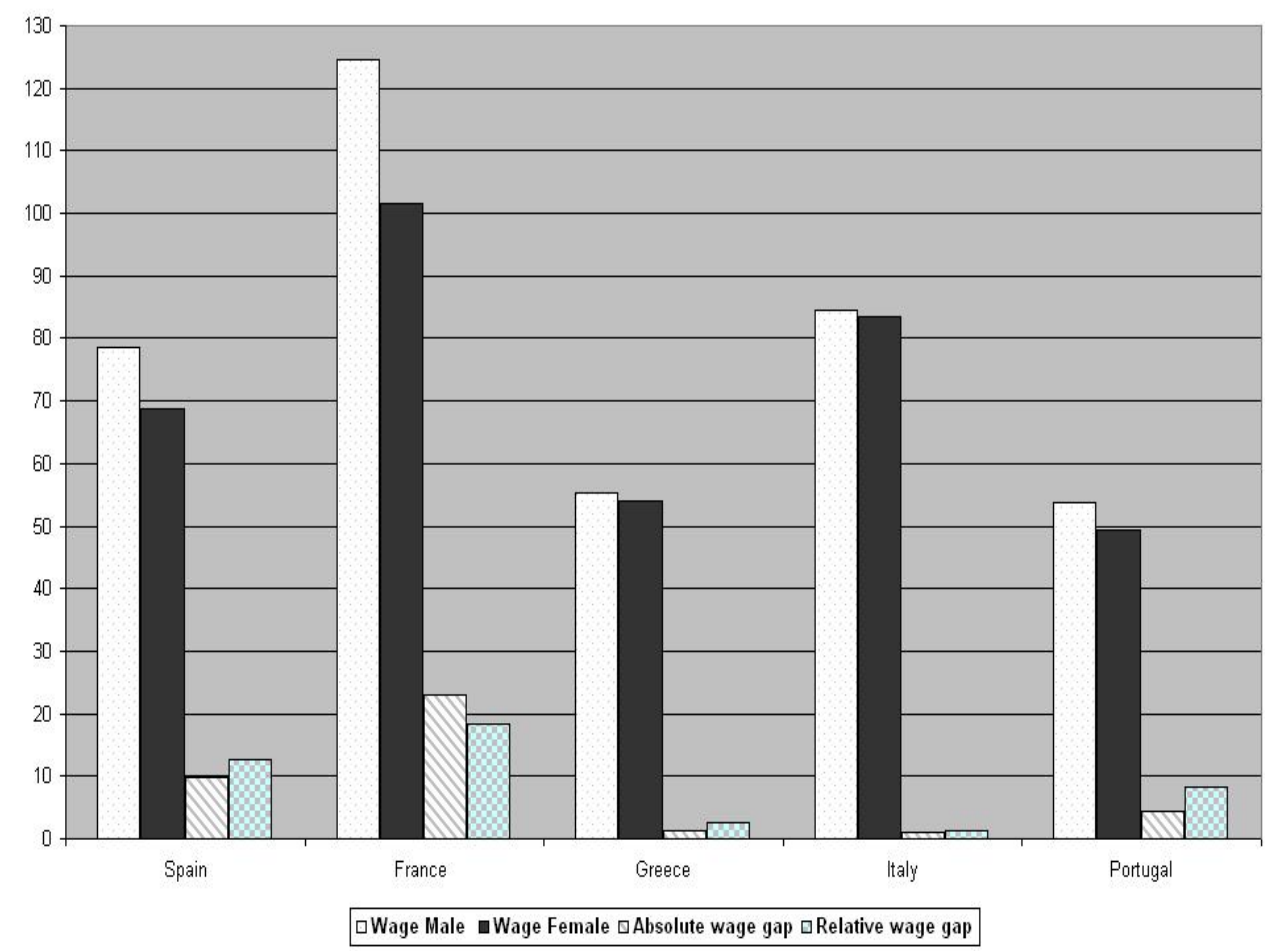

Data source: EU-SILC average hourly wage, husband and wife in working age, who are

employed at least 8 hours per week.

\section{The adjusted gender pay gap}

Male and female workers differ with respect to many characteristics, including the length of work experience, the level of education and skills, the occupational status and the sector of employment. Each of these characteristics has some association with the level of earnings so the unadjusted pay gap does not compare like with like. It is appropriate to decompose the gender pay gap to distinguish what proportion of the overall pay gap is due to differences in individual characteristics and what proportion is due to sex discrimination within the labor market. This method is called the adjusted gender pay gap and it offers clarity by identifying the pay differential between male and female workers after controlling for differences in individual characteristics.

Most empirical studies of wage discrimination between men and women use a formal statistical technique first devised by Oaxaca (1973), building 
on Becker's (1971) well-known theory of labor market discrimination (see also Blinder 1973).

The decomposition approach of Oaxaca develops the concept of discrimination, considering the individual employee productive characteristics (such as level of education, years of work experience and so on) that can be used as approximations of his or her marginal productivity. Certain individual characteristics can be identified as associated with a person's productive capability and this, in turn, is associated with the wages earned.

The Oaxaca method is used to check for differences in characteristics between men and women. More formally, following Mincers (1974), a wage equation that relates to the logarithm of earnings as a function of individual characteristics is specified as:

$$
\underbrace{\ln {\overline{W_{i}}}^{H}-\ln \bar{W}_{i}^{W}}_{\text {Raw wage gap }}=\underbrace{\beta^{H}\left({\overline{X_{i}}}^{H}-\bar{X}_{i}^{W}\right)}_{\text {Endowment }}+\underbrace{\left(\bar{\beta}^{W}-\bar{\beta}^{W}\right) \bar{X}_{i}^{W}}_{\text {Discrimination }}
$$

where $\ln W_{i}$ represents the average earnings evaluated by an earnings equation, the indices $\mathrm{H}$ and $\mathrm{W}$ represent husband's and wife's earnings respectively, $X_{i}$ is the average characteristics and $\beta$ is the estimated returns on these characteristics.

The gap in the average earnings (expressed as a logarithm) can be broken down in two parts: the first represents the difference in observable human capital of men and women (endowment effects), and the second represents the unexplained component (interpreted as wage discrimination) which includes a difference due to unobservable factors that influence productivity and a difference due to differential reward for equal characteristics called remuneration effects or discrimination effects.

In Oaxaca's (1973) original application, separate estimates are obtained using both the male and the female weighting procedure to establish a range of possible values. All methods of decomposition of the wage gap must deal with the problem of the choice of weighting. In equation (1), differences in characteristics are weighted by the average male returns, and differences in returns are weighted by the average female characteristics. Here we have chosen to use the method proposed by Oaxaca and Ransom (1994). This involves the construction of a nondiscriminatory norm for returns on individual characteristics; the wage gap is then expressed as the sum of an advantage for men and a disadvantage for women, and the difference between characteristics valued at the norms returns.

In the last section we use and explain the quantile regression method proposed by Koenker and Basset (1978) and apply the new methods of estimation proposed in Machado and Mata in 2005 and Melly in 2006, to estimate the wage decomposition. These new techniques are more flexible and give more information on the wage gap distribution considering not only the means of variables but also the difference at various quantiles of wage distributions. 


\section{The Oaxaca-Blinder decomposition method}

When we want to estimate the wage equation for married women we face the problem of the selection bias. We have selection bias because the dependent variable of the wage equation can be measured only if the individual participates in the labor market. The literature offers estimators to correct this problem (Heckman 1979, Powell 1994).

We can write the wage equation as a combination of Mincerian explanatory variables:

$$
\ln \left(W_{i}^{J}\right)=X_{i}^{J} \beta+\mu_{i}^{J}, \quad J=H, W
$$

where $\ln \left(W_{i}\right)$ is the logarithmic wage for husband and wife $(\mathrm{H}, \mathrm{W}), X_{i}$ is a vector of explanatory variables such as age, experience, education, etc. and $\mu_{i}^{J}$ is an i.i.d. error term.

Almost all studies fit the wage by the OLS (Ordinary Least Square) equation and estimate the gender gap, but normally a significant part of the sample of wives does not work, which may be a non-random sample of all married women if there are variables that affect participation in the labor force. If so, then OLS on the sample of working women will be biased and inconsistent. The difference between workers and non-workers determines the sample selection bias because some components of the work decision are relevant to determining the wage process. Moreover, the unobservable characteristics affect the work decision and the wage.

To correct the selection, Heckman (1979) proposed two methods: maximum likelihood estimation and estimation of the wage equation in two steps, first estimating the female participation equation and calculating a correction term, called lambda or the inverse Mill's ratio, and then estimating by simple regression the wage equation in order that the corrections terms are added as an independent variable.

We can write the participation equation as:

$$
\begin{gathered}
q_{i t}^{*}=a_{i}+\beta X_{i t}+v_{i t} \\
\mathbf{q}_{\mathbf{i t}}=1\left[q_{i t}^{*} \geq 0\right]
\end{gathered}
$$

where $q_{i t}^{*}$ is a the participation equation of wives in the labor market, and depends on a vector of explanatory variables $\left(X_{i t}\right)$ as age, education, children and no-labor income. We observe the participation equation only if the selection indicator function $q_{i t}$ is equal to 1, i.e. only if the women are participating on the labor market.

We calculate the inverse Mill's ratio as:

$$
\lambda_{\mathbf{i}}\left(\mathbf{Z}_{\mathbf{i}} \gamma\right)=\frac{\phi\left(Z_{i} \gamma\right)}{\Phi\left(Z_{i} \gamma\right)}
$$


where $\phi(\cdot)$ and $\Phi(\cdot)$ denote the probability density and cumulative distribution functions of the standard normal distribution.

As a second stage we estimate the wage equation for married women with the OLS approach, so the equation becomes:

$$
\ln (W)=\beta^{\prime} X_{i}+\lambda+\mu_{i}
$$

where $\ln (W)$ is the logarithm of the hourly wage and is observed only for workers, $X_{i}$ are observed variables related to labor supply characteristics (potential work experience, education level) and labor demand characteristics (type of occupation, size of the firm, permanent or temporary contract and full time or part time job), $\lambda$ is the error correct term, and $\mu_{i}$ is the error term that includes all unobserved determinants of wages.

The Heckman model requires three assumptions: joint normality of the distribution of the error terms in the participation and wage equations; both error terms are independent of both sets of observable variables; and the final assumption is the standard normalization for the probit selection equation.

When we apply the Oaxaca-Blinder decomposition and the wage equation is corrected for selection, we have three effects: endowment, remuneration and selection.

The raw gender gap is calculated as follows:

$$
\underbrace{\Delta \ln (W)}_{\text {Raw wage gap }}=\underbrace{\beta^{H}\left(\bar{X}^{H}-\bar{X}^{F}\right)}_{\text {Endowment }}+\underbrace{\left(\bar{\beta}^{H}-\bar{\beta}^{F}\right) \bar{X}^{H}}_{\text {Discrimination }}+\underbrace{\left(\lambda^{H} \widehat{\theta}^{H} \lambda^{F} \widehat{\theta}^{F}\right)}_{\text {Selection }}
$$

where the last term is the selection effect and $\widehat{\theta}$ is an estimate of $\rho \sigma_{\mu}$.

Normally the $\widehat{\theta}^{H}$ is equal to zero, because there is not male selection, while the selection for females is $\widehat{\theta}^{F}>0$. When we consider the sample selection, the impact on the remuneration and endowment effectss is ambiguous. In several empirical studies the results differ when applying the Heckman method and OLS. In Miller and Rummery (1991) the endowment effects declines and the remuneration effects increases. In a study by Miller (1987) both effects decline.

\section{Wage gap estimation}

\section{Results of the Oaxaca-Blinder decomposition}

We estimate the wage equation with the simple OLS methods for husbands and the Heckman techniques for wives. We use the Oaxaca decomposition to investigate the gender gap in the family. 
The explanatory variables we use to estimate the wage equation with OLS are: experience, experience square, ${ }^{2}$ three levels of education (postgraduate, secondary, less than secondary), job characteristics such as firm size, sector and occupational groups when husbands and wives work at least 8 hours per week.

The participation equation to obtain the correct term for the wife wage equation is composed of: age, age square, children with three different age levels, education and household income without the wife's earnings.

In figures 4 to 7 we analyze the Oaxaca decomposition over the period 1994 and 2001, where the wage equation is estimated with an OLS and a Heckman methods.

The decomposition by the OLS method identifies the explained and discrimination part of the gender gap, while with the Heckman method we have a third component: the selection effect. We observe that the endowment effects estimated with the OLS in 1994 (see Figure 4), are negative in France, Spain, Italy and Greece and positive and very high only in Portugal. The endowment effects or characteristics effects when negative means that in a labor market with no discrimination females should expect to have higher wages than males. This is explained by the fact that females exhibit higher education than males. However, the discrimination effects in the labor market is more than compensated for by the endowment effects, and consequently means that males receive higher wages than females.

In figure 5, we report the wage decomposition in 2001 estimated by the OLS. Discrimination increased in Portugal and decreased in the other Mediterranean countries. In France and Spain the endowment effects increased and as a consequence discrimination decreased, while Italy and Greece continued to have a negative and increasing endowment effects.

We show in figures 6 and 7 the wage decomposition corrected for selection bias. The framework is different from the OLS estimation.

The Heckman method reveals that the potential wage gap between women and men, in the absence of selection, would be lower than that observed. The selection effects increased in each country in 2001 in comparison to 1994, while the discrimination effects or remuneration effects increased in Portugal by about $20 \%$, decreased in France, the U.K., Germany and The Netherlands by about $20 \%$ and in Italy decreased about $40 \%$. The wage differential explained by different characteristics of women and men increased in almost all countries in 2001.

\footnotetext{
${ }^{2}$ We use potential experience, calculated as age minus age when starting first job. We are not able to use actual experience because in the ECHP we do not have information on previous work life before entering the survey.
} 


\section{Quantile regression and wage decomposition}

In recent years a new literature has estimated the gender pay gap based on the quantile regression, by looking at the effects of gender and other covariates on different quantiles of log wage distribution and not only at the average of variables.

Koenker-Basset (1978) proposed a complete by new and different method of calculating the quantile regression that can be estimated by minimizing in $\beta(\tau)$ the following expression:

$$
\widehat{\beta}(\tau)=\min n^{-1}\left[\sum_{i}^{n} \rho_{\tau}\left(Y_{i}-X_{i} \beta\right)\right],(i=1, \ldots . . n),
$$

with the check function $\rho_{\tau}$ weighting the residuals $\mu_{i}$ asymmetrically:

$$
\rho_{\tau}\left(\mu_{i}\right)= \begin{cases}\tau \mu_{i} & \text { if } \mu_{i} \geq 0, \\ (\tau-1) \mu_{i} & \text { if } \mu_{i}<0 .\end{cases}
$$

Starting from the study of Koenker-Basset (1978), Machado and Mata (M-M) in 2005 proposed a method to extend the traditional Oaxaca-Blinder decomposition based on the quantile regression. Considering two groups, 0 and 1 , whose stochastic characteristics for each group are $X_{0}$ and $X_{1}$, the regression quantile can be written for each group as:

$$
Q_{y}(Y \mid X)=X_{i} \beta(\tau) \quad \forall \tau, i \in(0,1)
$$

where $Y \mid X$ is the conditional quantile. M-M propose an estimation of the counterfactual unconditional wage distribution, generate a random sample of size $m$ from a uniform distribution $U[0,1]$, and then calculate the conditional quantile regression for each group. They simulate the wage distribution of the second group on the basis of the wage distribution and the characteristics of the first group, and repeat these steps $m$ times.

The difference of the unconditional quantiles between the two groups can be decomposed as:

$$
\begin{aligned}
& \widehat{F}_{Y 1}^{-1}(\theta \mid T=1)-\widehat{F}_{Y 0}^{-1}(\theta \mid T=0)=\underbrace{\widehat{F}_{Y 1}^{-1}(\theta \mid T=1)-\widehat{F}_{Y 1}^{-1}(\theta \mid T=0)}_{\text {Characteristics }} \\
+ & \underbrace{\widehat{F}_{Y 1}^{-1}(\theta \mid T=0)-\widehat{F}_{Y 0}^{-1}(\theta \mid T=0)}_{\text {Coefficients }}
\end{aligned}
$$

where $\widehat{F_{Y t}^{-1}}(\theta \mid T=t)$ denotes the $\theta^{\text {th }}$ quantile of wage $Y$ for groups $t$ 's while $\widehat{F}_{Y 1}^{-1}(\theta \mid T=0)$ is the counterfactual unconditional wage distribution. 
Normally it is easy to estimate the conditional distribution function by inverting the conditional quantile function. However, the estimated conditional quantile function is not necessarily monotonic and so it may not be easy to invert it.

Melly in 2006 proposed integrating the conditional distributions over the range of covariates in order to obtain an estimate of the unconditional distribution. Melly showed that if the number of steps $m$ repeated in M$\mathrm{M}$ goes to infinity the procedure of the decomposition is the same as M-M when both the sample size and the number of quantiles are sufficiently large. Melly first estimates the conditional distribution of $Y_{t}$ :

$$
F_{y t}\left(q \mid X_{i}\right)=\int_{0}^{1} 1\left(F_{y t}^{-1}\left(\tau \mid X_{i}\right) \leq q\right)=\int_{0}^{1} 1\left(X_{i} \widehat{\beta}_{t}(\tau) \leq q\right) d \tau
$$

An estimator of the conditional distribution of $Y_{t}$ given $X_{i}$ at $q$ is:

$$
\widehat{F_{y t}}\left(q \mid X_{i}\right)=\int_{0}^{1} 1\left(X_{i} \widehat{\beta}_{t}(\tau) \leq q\right) d \tau=\sum_{j=1}^{n}\left(\tau_{j}-\tau_{j-1}\right) 1\left(X_{i} \widehat{\beta}_{t}(\tau) \leq q\right)
$$

This implies that the unconditional distribution function can be written as:

$$
\widehat{F_{y t}}(q \mid T=t)=\frac{1}{n_{t}} \sum \widehat{F_{y t}}\left(q \mid X_{i}\right)
$$

The unconditional and counterfactual quantiles distribution are respectively:

$$
\begin{aligned}
& \widehat{q_{t}}(\theta)=\inf \left\{q: \frac{1}{n_{t}} \sum_{t} \widehat{F_{y t}}\left(q \mid X_{i}\right) \geq \theta\right\} \\
& \widehat{q_{c} 1}(\theta)=\inf \left\{q: \frac{1}{n_{t}} \sum_{0} \widehat{F_{y t}}\left(q \mid X_{i}\right) \geq \theta\right\}
\end{aligned}
$$

The decomposition of the difference between the $\theta^{\text {th }}$ quantile of the unconditional distribution of two groups is:

$$
\widehat{q_{1}}(\theta)-\widehat{q_{0}}(\theta)=\underbrace{\widehat{q_{1}}(\theta)-\widehat{q_{c 1}}(\theta)}_{\text {characteristics }}+\underbrace{\widehat{q_{c 1}}(\theta)-\widehat{q_{0}}(\theta)}_{\text {coef ficients }}
$$

Selection bias is present when the outcome of interest is only observable for a subsample of individuals. Heckman in 1974 and 1979 proposed a parametric estimator to estimate covariates with selection bias. This approach is inconsistent if the error term is misspecified. Powell (1987)and Newey(1991) proposed a semi-parametric estimator for the sample selection model. More recently Das, Newey and Vella(2003) proposed a nonparametric estimator for this model. Buchinsky in 1998 and 2001 was the first to apply the semiparametric sample selection model for quantile regression. 
Concerning the selection in the wage equation of women, we follow the Buchinsky (1998a) estimation. We calculate the quantile regression of women as:

$$
Q_{y}\left(Y_{w} \mid X\right)=X \beta_{w}(\tau)+h_{\tau}\left(z_{w} \gamma\right) \quad \forall \tau \in(0,1)
$$

The vector $Z$ is a set of observable characteristics that influence the probability that a woman participates in the labor market. These variables are uncorrelated with the log of the wage and they are: dummy for children with different ages, education, age, age square, household income without wife's earnings, unemployment benefit of their husbands, if they receive it.

The term $h_{\tau}\left(z_{w} \gamma\right)$ correct the selection at $\theta^{\text {th }}$ quantile. It represents the inverse Mill's ratio in the Heckman method. To estimate this term Buchinsky (1998a) suggests a series of estimators, we consider this one:

$$
h_{\tau}\left(z_{w} \gamma\right)=\imath \delta_{0}(\tau)+\delta_{1}(\tau) \lambda\left(z_{w} \gamma\right)+\delta_{2}(\tau) \lambda\left(z_{w}\right)^{2}
$$

The asymptotic distribution of $\beta(\tau)$ for a given quantile $\tau$ is a non iid setting. We calculate the asymptotic variance of $\sqrt{n X_{i}} \widehat{\beta}_{t}\left(\tau_{j}\right)$ using the "Hendricks-Koenker sandwich" following Hendricks and Koenker (1992), Koenker (2005), and Melly (2006), and we correct the standard error with a bootstrap estimation for 100 times.

\section{Empirical Results of Quantile Regression}

The estimation of the wage gap between husbands and wives, following the method described above, is reported in Figures 9 to 13 for each country that we take into consideration in this paper and the different data set used: ECHP in 2001 and EU-SILC in 2006.

We can test several hypotheses such as the presence of a glass ceiling or sticky floors. Usually, the literature has identified the existence of a glass ceiling when the pay gap is significantly larger at the top of the distribution and a sticky floor when the wage gap is larger at the bottom. We define the existence of a glass ceiling if the $95^{\text {th }}$ percentile wage gap is higher than $2 \%$ with respect to $50^{t h}$ percentile while the sticky floor effect exists if the $10^{t h}$ percentile wage gap is higher than the $25^{\text {th }}$ percentile by at least $2 \%$.

Looking at the wage gap distribution in 2001 with the ECHP data we see that it is positive and its distribution varies greatly across quantiles (Figures 9-13). In table 3 we analyze the wage gap and its components for each country in different quantiles $\left(10^{\text {th }}, 25^{\text {th }}, 50^{\text {th }}, 75^{\text {th }}\right.$ and $\left.95^{\text {th }}\right)$.

We can see that the first component, the characteristics effects, is equally distributed among quantiles in each country between wives and husbands (Figures 9-13), and the proportion of the observed wage gap that is explained by the differences in returns to characteristics is very low along the wage distribution. 
A negative percentage value implies that women have better characteristics than men that compensate them for discrimination. The negative characteristics are present in the Mediterranean countries at the top of the wage distribution. These results confirm that husbands and wives have the same characteristics when they get married, a result that we can find in Del Boca-Flinn (2006), Chiappori et al (2007)

The second component of the wage gap is the coefficient effects. This effect is positive and explains most of the wage gap (Table 3 ) in all countries, so the gender gap is also positive and varies across the wage distribution.

In table 3 we present the results of the quantile regression and we can check the existence of a sticky floor or a glass ceiling in Mediterranean countries with the ECHP in 2001.

According with our definition of sticky floor and glass ceiling effects, we have found that Spain, Italy, Greece and France suffer a sticky floor effect. Women at the bottom $\left(10^{\text {th }}\right.$ percentile $)$ are more disadvantaged with respect to those at the $25^{\text {th }}$ percentile. Portugal presents a positive discrimination which is high for the quantiles between $10^{t h}$ and $70^{t h}$.

The glass ceiling effect is present only in France according to the definition we have used.

The same analysis was carried out for the EU-SILC data set in 2006. We always find a positive gender pay gap (Figures 9-13). The characteristics effects are move up for France, Greece, Spain and Italy especially at the bottom of the wage distribution. In Portugal it continues to be negative, increasing not only in the last $50^{\text {th }}$ quantiles but also at the bottom of the distribution. Negative characteristics effects have the same significance that we explained above using the Oaxaca method.

The coefficient effect has suffered the same increase, but only at the bottom of distribution, while it has gone down at the top of it.

To check for sticky floor and glass ceiling in 2006 in Mediterranean countries we can see table 4 . We f find that all countries except Portugal show a wage gap greater that $2 \%$ at the bottom of the wage distribution respect to the $50^{\text {th }}$ quantile. We continue to find the glass ceiling in France, while in other countries the difference between the $50^{\text {th }}$ and $90^{\text {th }}$ quantile has decreased.

Figure 11 presents a scatter plot illustrating the correlation for European countries between the sticky floor phenomena and the OECD work-family index. This index is a group of indicators that sum up the family policies such as child-care, maternity leave, flexi-time etc. The graph shows that the work-family index is negative correlated with the country that suffers the sticky floor effect. Countries with not very generous work-family policies have a bigger wage gap at the bottom of the distribution. 


\section{Discussion and Conclusions}

This work shows different techniques of decomposing the wage gap between husbands and wives. We find that the distribution of characteristics is the same between husband and wife but the wages that they receive are different.

Mediterranean women with large gender differences in earnings opportunities reinforce traditional divisions of labor at the household level, preventing individuals and couples from deciding on a different organization of the household and caring responsibilities.

The wage gap is more evident for married women at the bottom of the wage distribution in Southern countries.

The women who receive low wages are normally less well educated and with a high rate of fertility, so family policies such as child care, parental leave and equal opportunities, or wage setting institutions or cultural traditions, are likely to affect gender wage gaps. Mothers are most likely to use parental leave with respect to fathers, implying that women reduce their work experience and undermine their earnings capacity. Another factor correlated with the gender gap is the occupational segregation that women are more exposed to. Women are caught up in some female-typed jobs (see table 5), where the economics opportunity in terms of powerful position and earnings are limited. The public sector is one of the most attractive sectors for women due to its protective nature, flexible working hours and greater tolerance to absenteeism (Esping-Andersen 1990). In the Mediterranean countries such types of jobs are traditionally mainly assigned to women.

Blau and Kahn (2003) show that the expected impact of the policies of parental leave and child care is unclear a priori; a woman who is not eligible for parental leave may lose her job or re-enter the labor market at a lower level after having a child, while women who do have access to parental leave might have higher relative earnings, due to the policy preserving their ties to the firms, so there is a correlation between parental leave and higher female pay.

Brayan et al in 2006 with the ECHP data showed that Southern countries with a strong tradition of family and poor family policies suffer from the phenomena of the sticky floor while Scandinavian countries with strong family policies are affected by the glass ceiling effect.

We find the same results with ECHP for husbands and wives in 2001. Figure 14 shows as Mediterranean countries with poor family policies are more subject to the sticky floor effect.

By applying the quantile regression procedure, we understand the different gender gap between husbands and wives in Mediterranean countries with a strong family tradition, along their wage distribution.

The gender pay gap is positive in all countries, and most of it is made up of the discrimination effect. While the characteristics effects are around zero and substantially the same across countries and across year, thus con- 
firming that men and women married partners with the same characteristics the return in coefficient are large and vary across the distribution and across countries. We observed that in 2006 the wage gap was greater with respect to 2001 and the glass ceiling phenomenon was less strong in all countries. Portugal confirmed it self as bring exception in the labor market in Mediterranean countries. 


\section{References}

Albrecht Aico van Vuuren Susan Vroman, 2004. Quantile regression with sample selection: Estimating women's return to education in the U.S.

Beblo, M., D. Beninger, A. Heinze and F. Laisney, 2003. Measuring Selectivity- Corrected Gender Wage Gap in EU. ZEW Mannheim, discussion paper No. 0374.

Becker, G. (1971). The Economics of Discrimination. Series: (ERS) Economic Research Studies.

Blinder, A. S. (1973), Wage Discrimination: Reduced Form and Structural Estimates, The Journal of Human Resources, 8(4), 436-455.

Chamberlain, G., 1980, Analysis with qualitative data, Review of Economic Studies 47, 225-238.

Blau F. D. and L. M. Khan, 1996. Wage structure and Gender Earnings Differentials: An international comparison, Economica 63.

Blau F. D. and L. M. Khan, 2003. "Gender Differences in Pay," NBER Working Papers 7732, National Bureau of Economic Research. De la Rica S.,

J. Dolado , V. LLorens, 2005. "Ceilings and Floors?: Gender Wage Gaps by Education in Spain," DFAEII Working Papers 200501 Employment in

Europe 2005. Brussels: European Commission.

García J., P. Hernandez and A. Lopez-Nicolas. 2001. How Wide is the Gap? An Investigation of Gender Wage Differences Using Quantile Regression. Empirical Economics. March, 26:1, pp. 14967.

Heckman, James J. 1979. Sample Selection Bias as a Specification Error. Econometrica. January, 47:1, pp. 15361.

Hendricks, Wallace and Roger Koenker. 1992. Hierarchical Spline Models for Conditional Quantiles and the Demand for Electricity. Journal of the American Statistical Association. March, 87:417, pp. 5868.

Koenker, Roger and Gilbert Bassett. 1978. Regression Quantiles. Econometrica. January, 46:1, pp. 3350.

Joshi, H. and P. Paci (1998). Unequal Pay for Women and Men. London: The MIT Press Cambridge. 
Machado, J., and J. Mata (2003), Counterfactual Decomposition of Changes in Wage Distribution Using Quantile Regression, mimeo, Universidade de Lisboa.

Melly B. 2006, Estimation of counterfactual distributions using quantile regression, Review of Labor Economics 68, 543-572.

Miller, P. W. (1987), Gender Differences in Observed and Offered Wages in Canada, 1980, The Canadian Journal of Economics, 20 (2), 225-24.

Mincer, J. (1974), Investment in Human Capital and Personal Income Distribution, Journal of Political Economy, 66(4), 281-302.

C. Nicoletti and F. Peracchi 2002: A cross-country comparison of survey participation in the ECHP, Working papers of the. Institute for Social and Economic Research.

Plasman R. and S. Sissoko, 2002. National Reports on the Unadjusted and Adjusted Gender Pay Gap in Belgium. European Expert Group on Gender and Employment Report to the Equal Opportunities Unit, DG Employment.

Oaxaca R. L. and M. Ransom, 1998. Calculation of approximate variance for wage decomposition differentials. Journal of Economic and Social Measurement 24, 55-61.

Oaxaca R., 1973. Male-Female Wage Differentials in Urban Labor Markets. International Economic Review 14, 693-709.

Rice, P. (1999), Gender Earnings Differentials: The European Experience, The World Bank Development Research Group, WP No.8.

Wooldridge, J.M., 2002, Econometric analysis of cross section and panel data. MIT Press: Cambridge, MA. 33 
Figure 4: Oaxaca-Blinder decomposition of the gender gap in European countries: OLS estimation in 1994

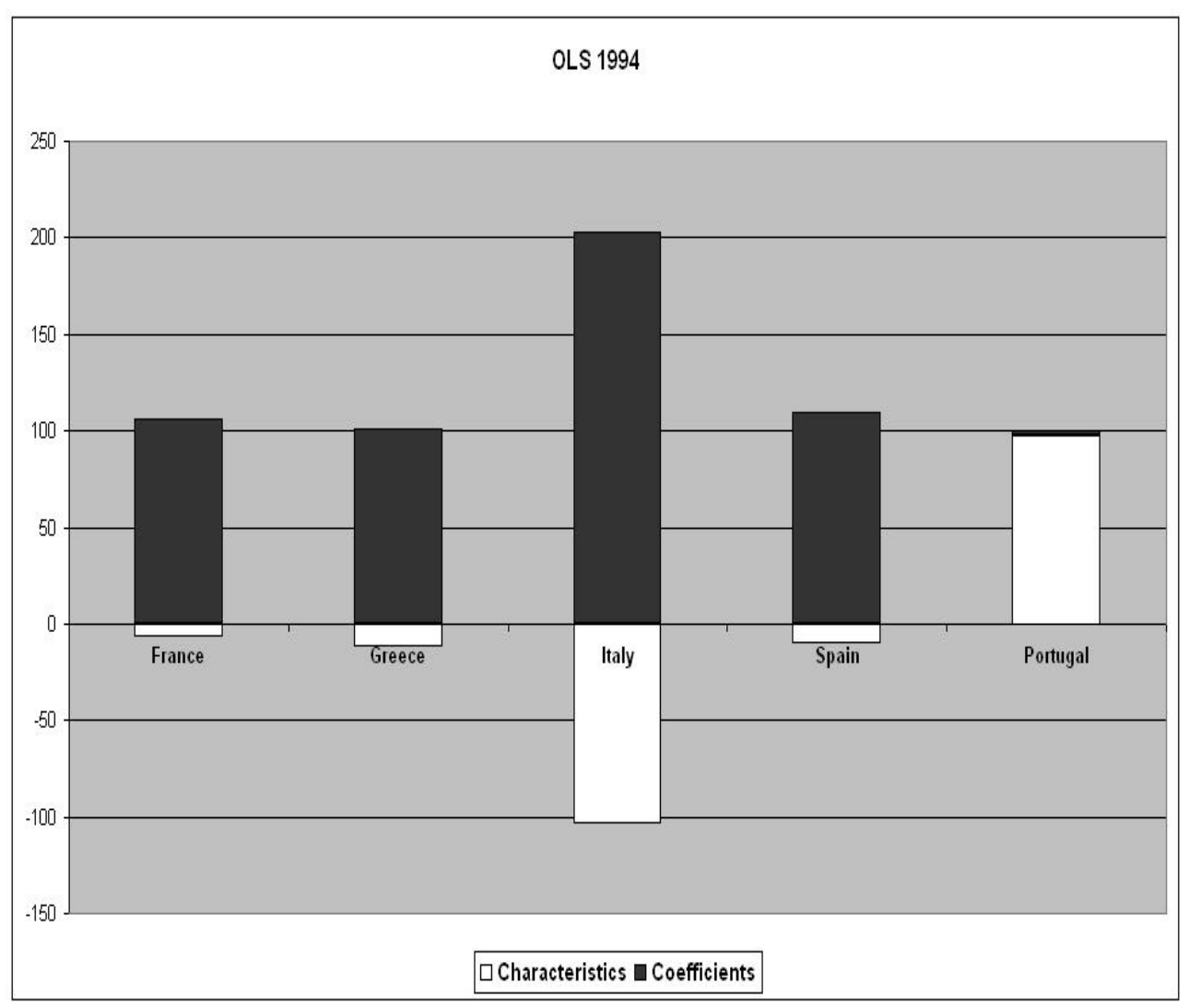

Source: ECHP, husband-wife who are employed at least 8 hours per week in 1994 
Figure 5: Oaxaca-Blinder decomposition of the gender gap in European countries: OLS estimation in 2001

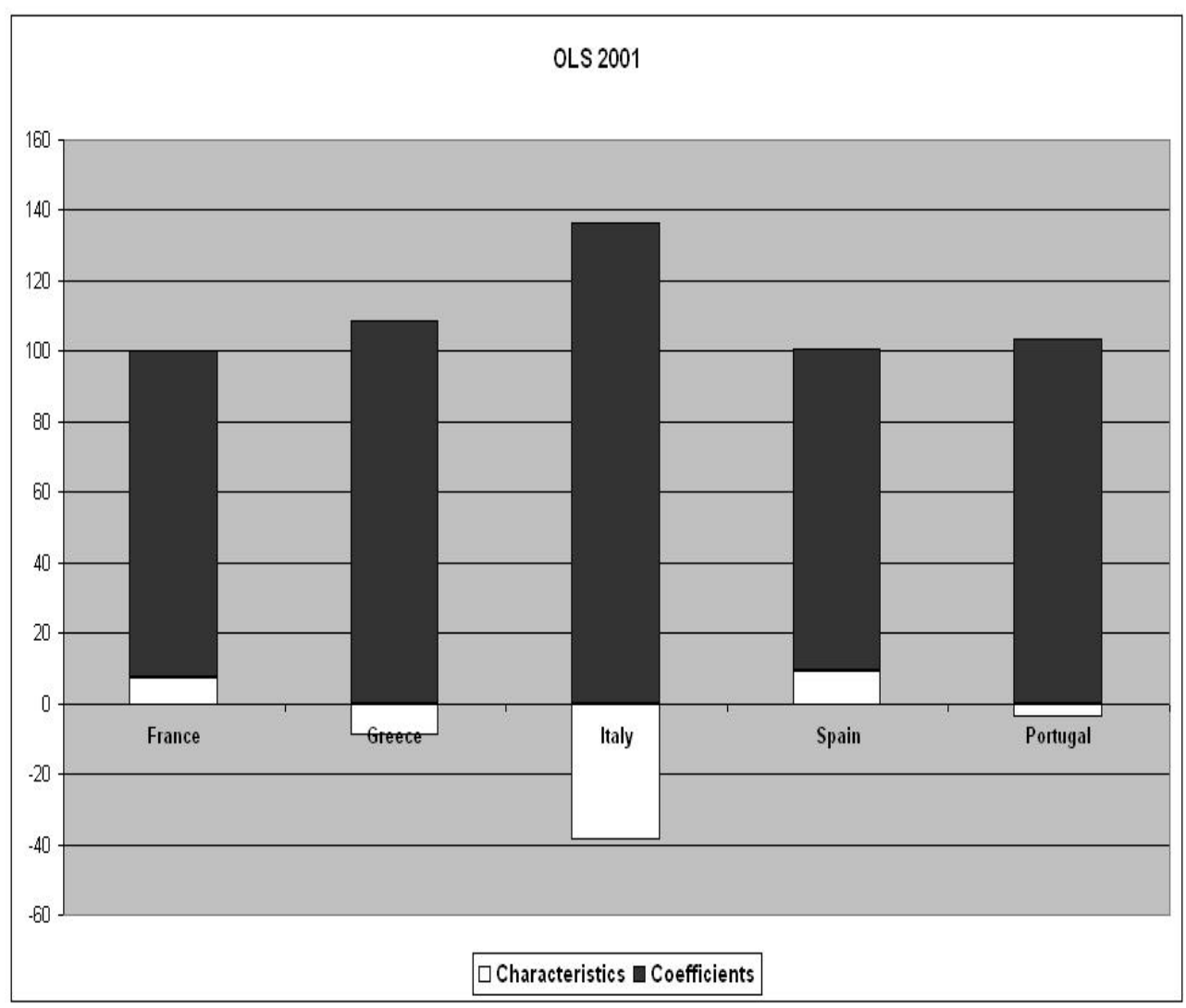

Source: ECHP, husband-wife who are employed at least 8 hours per week in 2001 
Figure 6: Oaxaca-Blinder decomposition of the gender gap in European countries: Heckman estimation in 1994

Heckman 1994

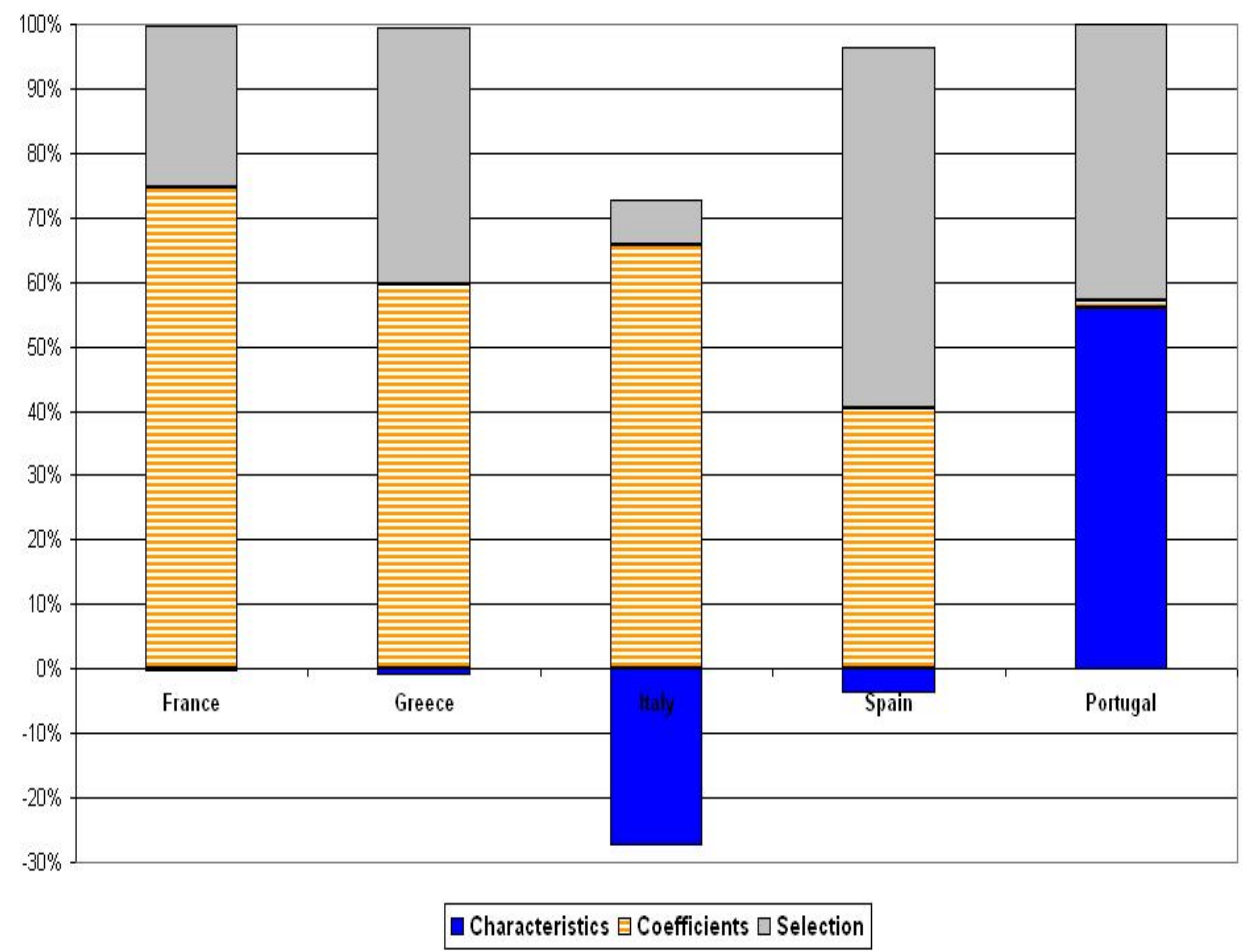

Source: ECHP, husband-wife who are employed at least 8 hours per week in 1994 
Figure 7: Oaxaca-Blinder decomposition of the gender gap in European countries: Heckman estimation in 2001

Heckman 2001

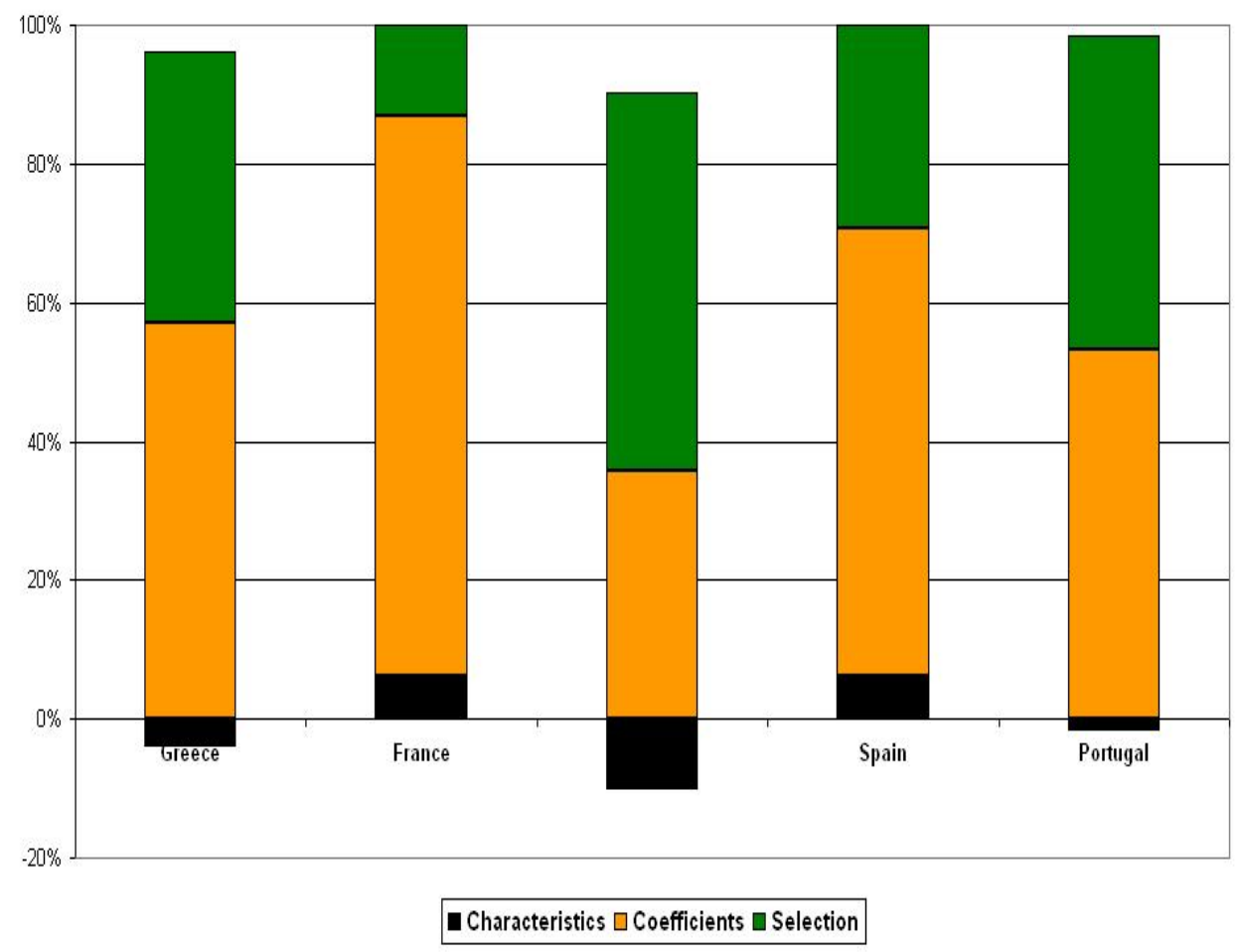

Source: ECHP, husband-wife who are employed at least 8 hours per week in 2001 
Figure 8: Oaxaca-Blinder decomposition of the gender gap in European countries: Heckman estimation in 2006

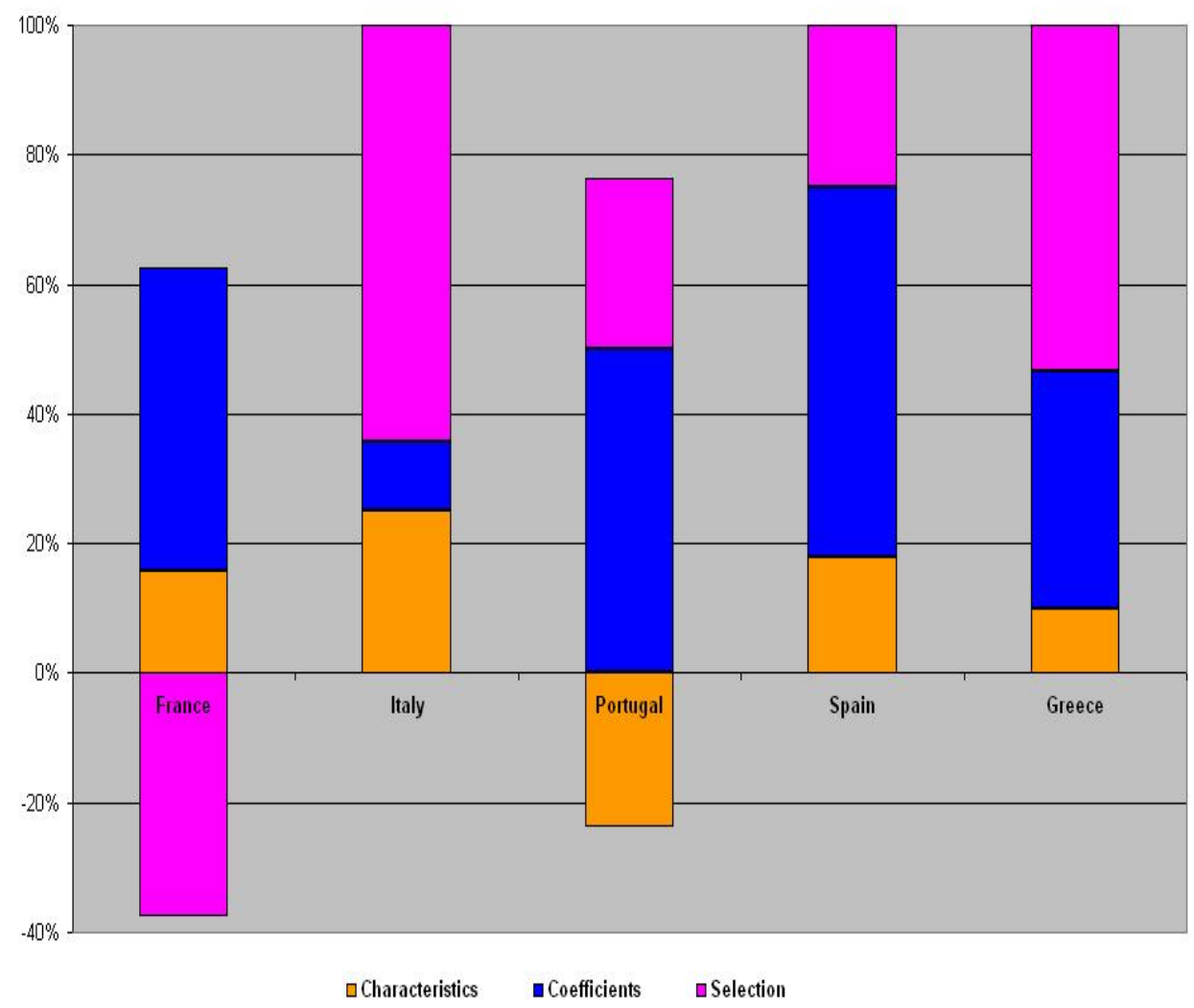

Source: EU-SILC, husband-wife who are employed at least 8 hours per week in 2006 
Figure 9: Quantile regression decomposition: France

\section{FRANCE}
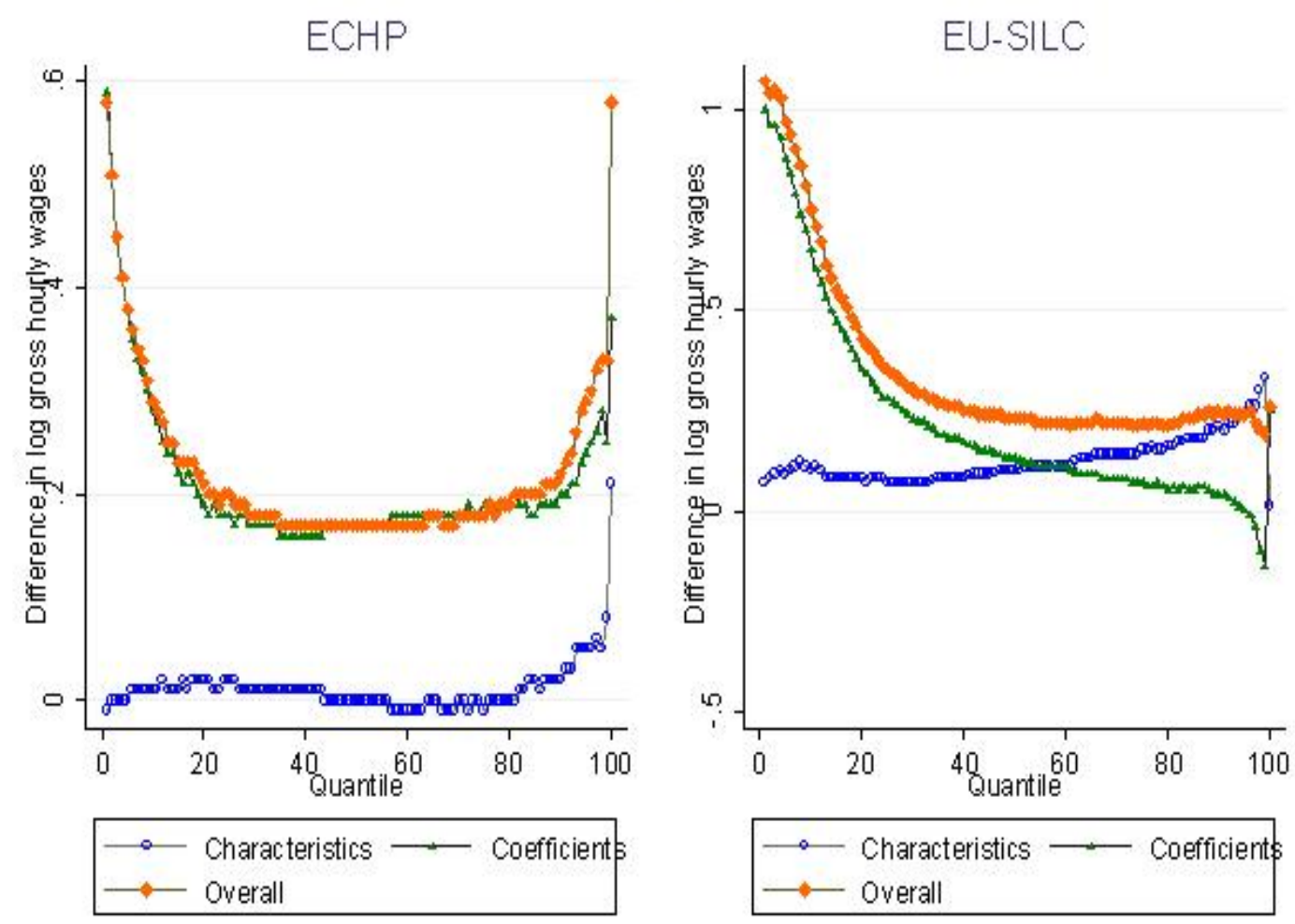

Source: ECHP and EU-SILC, husband-wife who are employed at least 8 hours per week 
Figure 10: Quantile regression decomposition: Greece

\section{GREECE}
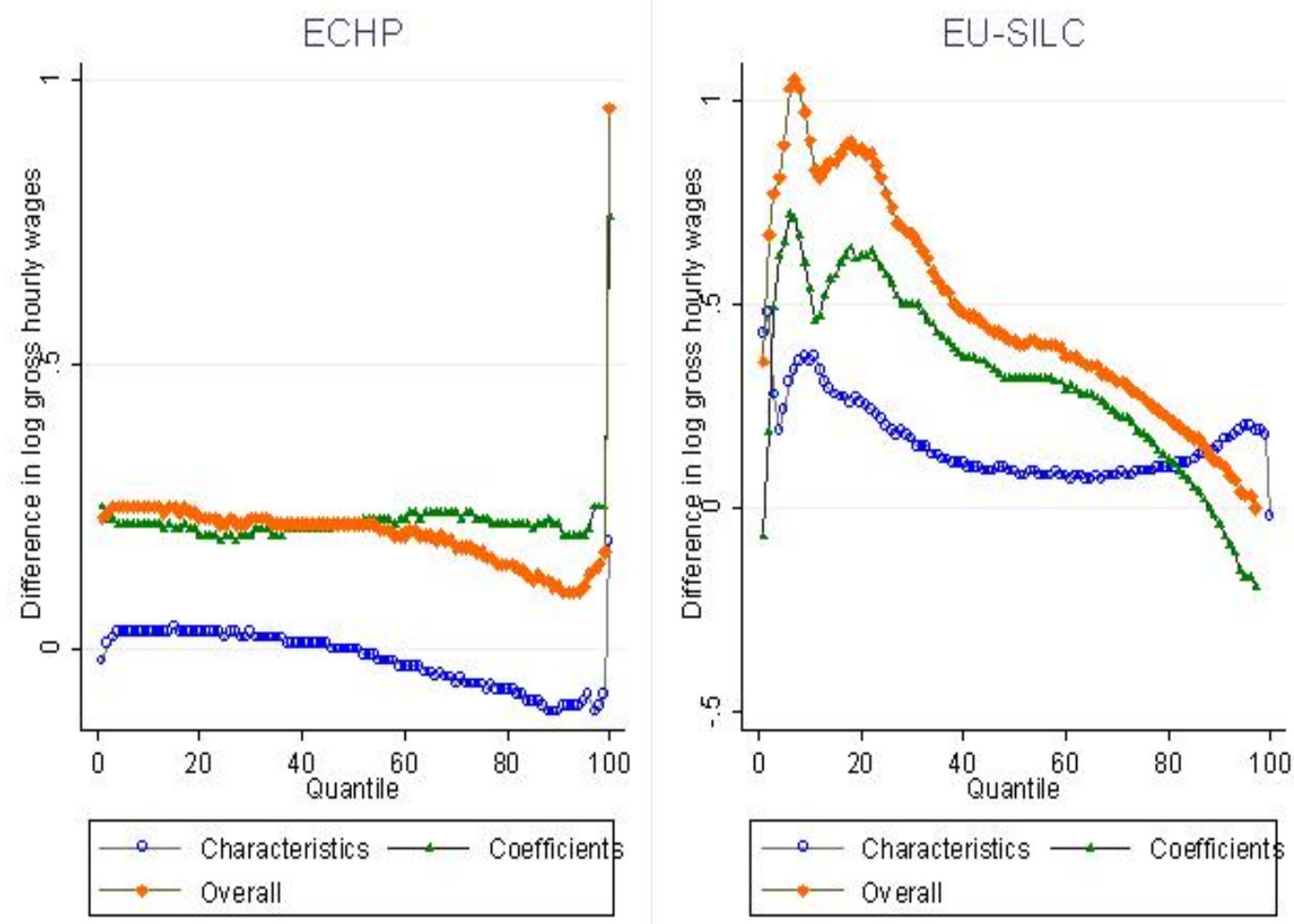

Source: ECHP and EU-SILC, husband-wife who are employed at least 8 hours per week 
Figure 11: Quantile regression decomposition: Italy

\section{ITALY}
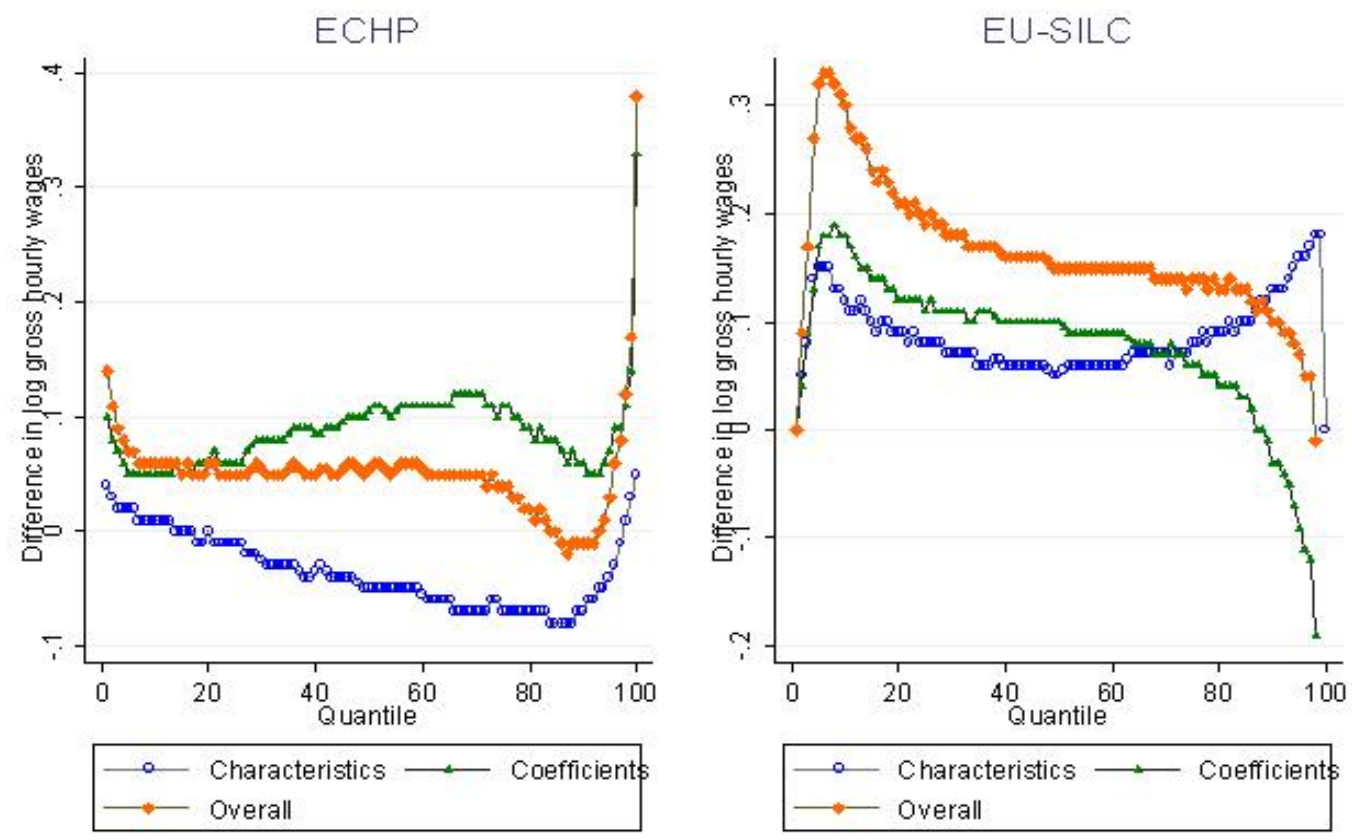

Source: ECHP and EU-SILC, husband-wife who are employed at least 8 hours per week 
Figure 12: Quantile regression decomposition: Spain

\section{SPAIN}
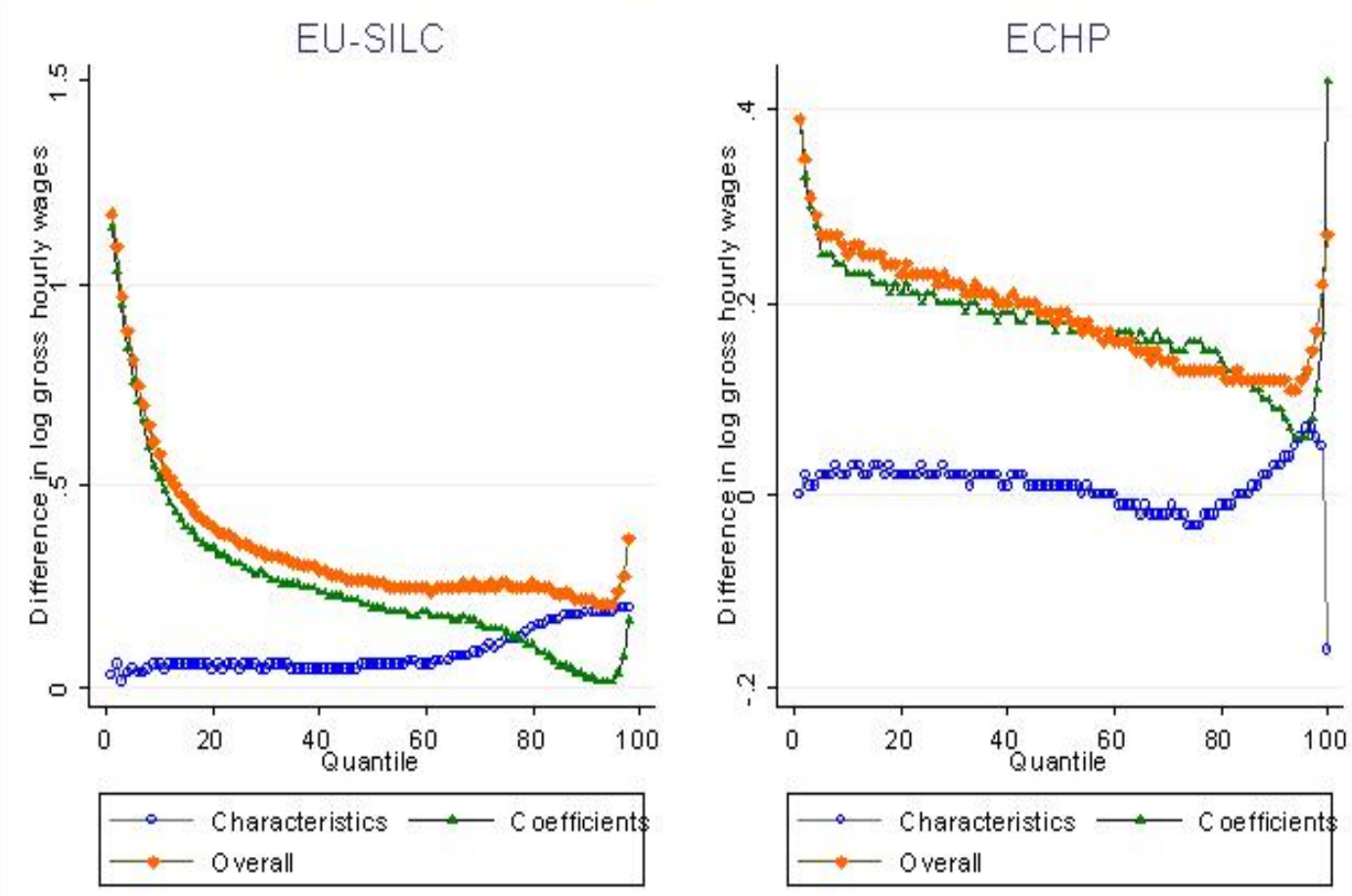

Source: ECHP and EU-SILC, husband-wife who are employed at least 8 hours per week 
Figure 13: Quantile regression decomposition: Portugal

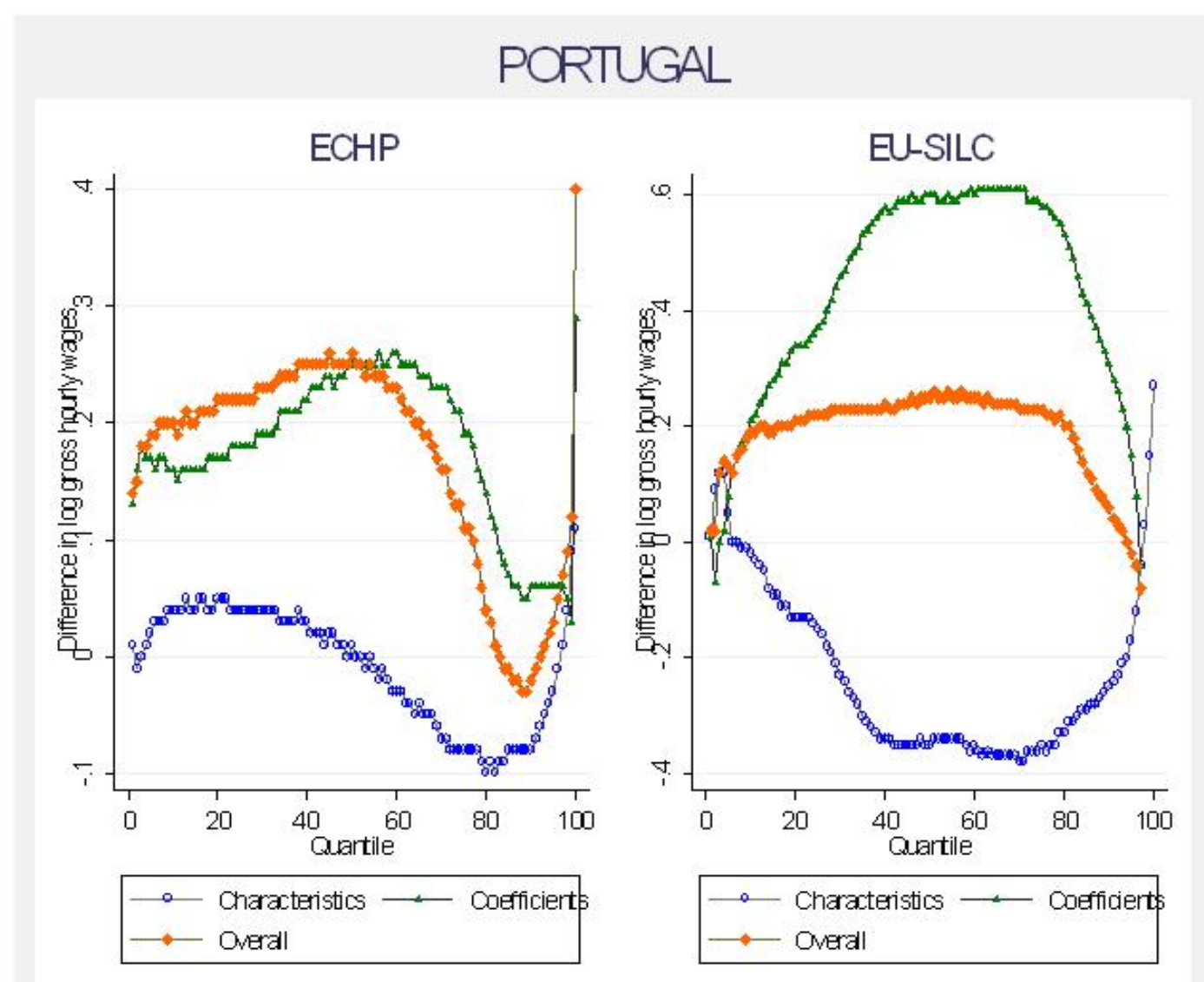

Source: ECHP and EU-SILC, husband-wife who are employed at least 8 hours per week 
Figure 14: Work-family reconciliation (OECD 2001 Index)

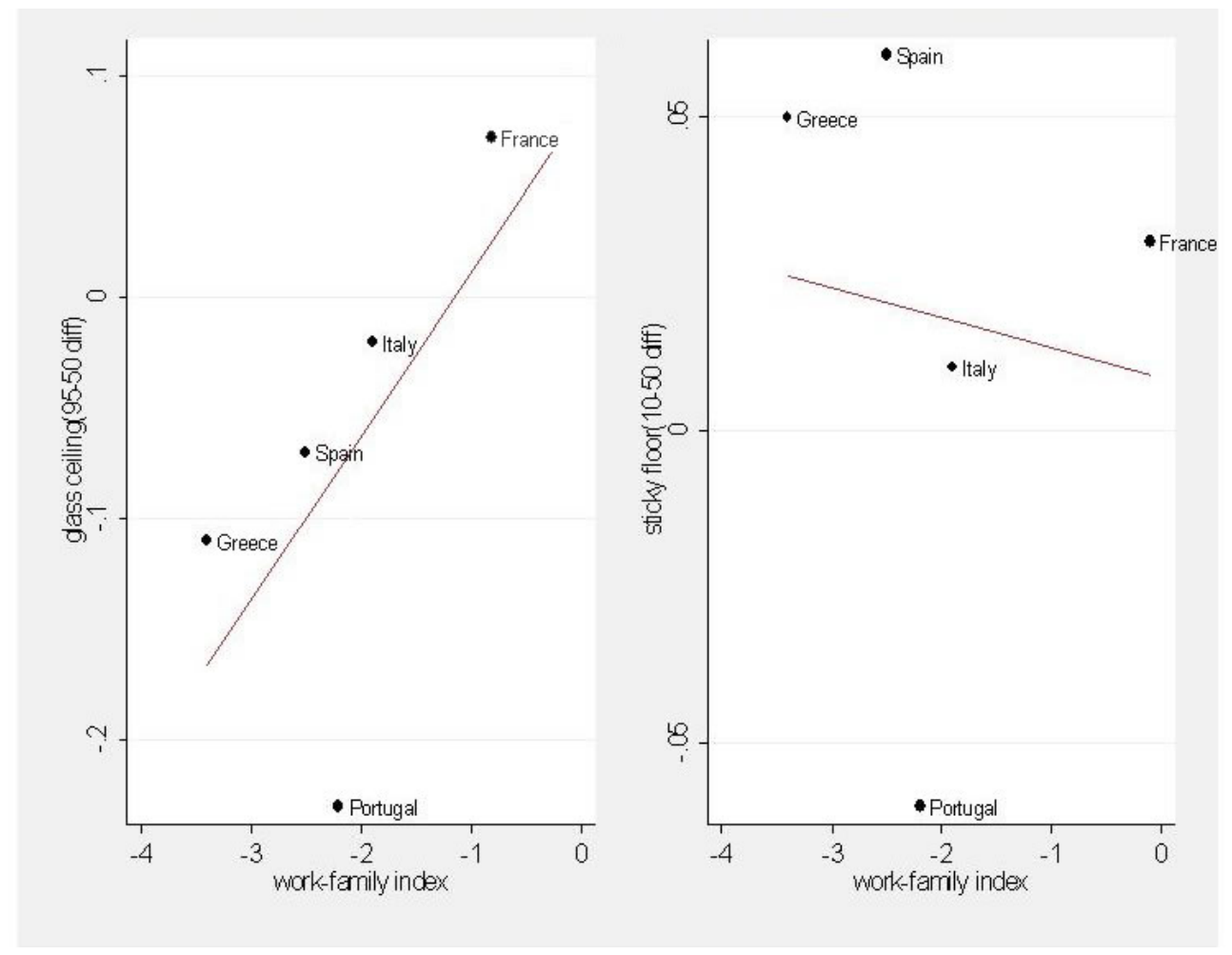

Source: ECHP, husband-wife who are employed at least 8 hours per week in 2001 
Table 3: Estimated Wage Gap: Characteristics and Coefficients effects in 2001 with ECHP data

\begin{tabular}{|c|c|c|c|c|c|c|c|}
\hline \multicolumn{4}{|c|}{ Spain } & & \multicolumn{3}{|c|}{ France } \\
\hline & $\begin{array}{l}\text { Coeffi- } \\
\text { cients }\end{array}$ & $\begin{array}{l}\text { Charac- } \\
\text { teristics }\end{array}$ & overall & & $\begin{array}{l}\text { Coeffi- } \\
\text { cients }\end{array}$ & $\begin{array}{l}\text { Charac- } \\
\text { teristics }\end{array}$ & Overall \\
\hline 10 & 0.23 & 0.02 & 0.25 & & 0.28 & 0.01 & 0.21 \\
\hline$\%$ & 92.00 & 8.00 & 37.31 & & 96.55 & 3.45 & 25.66 \\
\hline 25 & 0.21 & 0.02 & 0.23 & & 0.18 & 0.02 & 0.20 \\
\hline$\%$ & 91.30 & 8.70 & 34.33 & & 90.00 & 10.00 & 17.70 \\
\hline 50 & 0.18 & 0.01 & 0.19 & & 0.17 & 0.00 & 0.18 \\
\hline$\%$ & 94.74 & 5.26 & 28.36 & & 100.00 & - & 15.04 \\
\hline 75 & 0.16 & -0.03 & 0.13 & & 0.19 & -0.01 & 0.18 \\
\hline$\%$ & 123.08 & -23.08 & 19.40 & & 105.56 & -5.56 & 15.93 \\
\hline 95 & 0.06 & 0.06 & 0.12 & & 0.24 & 0.05 & 0.29 \\
\hline \multirow[t]{3}{*}{$\%$} & 50.00 & 50.00 & 17.91 & & 82.76 & 17.24 & 25.66 \\
\hline & \multicolumn{3}{|c|}{ Greece } & & \multicolumn{3}{|c|}{ Portugal } \\
\hline & $\begin{array}{l}\text { Coeffi- } \\
\text { cients }\end{array}$ & $\begin{array}{l}\text { Charac- } \\
\text { teristics }\end{array}$ & Overall & & $\begin{array}{l}\text { Coeffi- } \\
\text { cients }\end{array}$ & $\begin{array}{l}\text { Charac- } \\
\text { teristics }\end{array}$ & Overall \\
\hline 10 & 0.22 & 0.03 & 0.27 & & 0.16 & 0.04 & 0.20 \\
\hline$\%$ & 88.00 & 12.00 & 25.77 & & 80.00 & 20.00 & 24.39 \\
\hline 25 & 0.20 & 0.02 & 0.22 & & 0.18 & 0.04 & 0.22 \\
\hline$\%$ & 90.91 & 9.09 & 22.68 & & 81.82 & 18.18 & 26.83 \\
\hline 50 & 0.22 & 0.00 & 0.22 & & 0.25 & 0.01 & 0.26 \\
\hline$\%$ & 100.00 & & 22.68 & & 96.15 & 3.85 & 31.71 \\
\hline 75 & 0.23 & -0.06 & 0.17 & & 0.19 & -0.08 & 0.11 \\
\hline$\%$ & 135.29 & -35.29 & 17.53 & & 172.73 & -72.73 & 13.41 \\
\hline 95 & 0.20 & -0.09 & 0.11 & & 0.06 & -0.03 & 0.03 \\
\hline \multirow[t]{13}{*}{$\%$} & 181.82 & -81.82 & 11.34 & & 200 & -100 & 3.66 \\
\hline & \multicolumn{7}{|c|}{ Italy } \\
\hline & & & $\begin{array}{l}\text { Coeffi- } \\
\text { cients }\end{array}$ & $\begin{array}{l}\text { Charac- } \\
\text { teristics }\end{array}$ & Overall & & \\
\hline & & 10 & 0.05 & 0.01 & 0.06 & & \\
\hline & & $\%$ & 83.33 & 16.67 & 25.53 & & \\
\hline & & 25 & 0.06 & -0.01 & 0.05 & & \\
\hline & & $\%$ & 120.00 & -20.00 & 21.28 & & \\
\hline & & 50 & 0.10 & -0.05 & 0.06 & & \\
\hline & & $\%$ & 190.91 & -90.91 & 23.40 & & \\
\hline & & 75 & 0.11 & -0.07 & 0.04 & & \\
\hline & & $\%$ & 275.00 & -175.00 & 17.02 & & \\
\hline & & 95 & 0.07 & -0.04 & 0.03 & & \\
\hline & & $\%$ & 233.33 & -133.33 & 12.77 & & \\
\hline
\end{tabular}


Table 4: Estimated Wage Gap: Characteristics and Coefficients effects in 2006 with EU-SILC data

\begin{tabular}{|c|c|c|c|c|c|c|c|}
\hline \multicolumn{4}{|c|}{ France } & & \multicolumn{3}{|c|}{ Portugal } \\
\hline & $\begin{array}{l}\text { Coeffi- } \\
\text { cients }\end{array}$ & $\begin{array}{l}\text { Charac- } \\
\text { teristics }\end{array}$ & overall & & $\begin{array}{l}\text { Coeffi- } \\
\text { cients }\end{array}$ & $\begin{array}{l}\text { Charac- } \\
\text { teristics }\end{array}$ & Overall \\
\hline 10 & 0.65 & 0.10 & 0.75 & & 0.21 & -0.02 & 0.19 \\
\hline$\%$ & 86.67 & 13.33 & 52.08 & & 110.53 & -10.53 & 29.23 \\
\hline 25 & 0.28 & 0.07 & 0.35 & & 0.37 & -0.15 & 0.22 \\
\hline$\%$ & 80.00 & 20.00 & & & 168.18 & -68.18 & 33.85 \\
\hline 50 & 0.13 & 0.10 & 0.23 & & 0.60 & -0.35 & 0.25 \\
\hline$\%$ & 56.52 & 43.48 & 15.97 & & 240.00 & -140.00 & 38.46 \\
\hline 75 & 0.07 & 0.15 & 0.22 & & 0.58 & -0.35 & 0.23 \\
\hline$\%$ & 46.67 & 68.18 & 15.28 & & 252.17 & -152.17 & 35.38 \\
\hline 95 & 0.00 & 0.24 & 0.24 & & 0.15 & -0.17 & -0.02 \\
\hline$\%$ & 0.00 & 100.00 & 16.67 & & -750.00 & 850.00 & -3.08 \\
\hline \multicolumn{4}{|c|}{ Spain } & & \multicolumn{3}{|c|}{ Greece } \\
\hline & $\begin{array}{c}\text { Coeffi- } \\
\text { cients }\end{array}$ & $\begin{array}{l}\text { Charac- } \\
\text { teristics }\end{array}$ & Overall & & $\begin{array}{l}\text { Coeffi- } \\
\text { cients }\end{array}$ & $\begin{array}{l}\text { Charac- } \\
\text { teristics }\end{array}$ & Overall \\
\hline 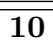 & 0.52 & 0.06 & 0.58 & & 0.54 & 0.36 & 0.90 \\
\hline$\%$ & 89.66 & 10.34 & 44.27 & & 60.00 & 40.00 & 55.90 \\
\hline 25 & 0.31 & 0.05 & 0.36 & & 0.57 & 0.20 & 0.77 \\
\hline$\%$ & 86.11 & 13.89 & 27.48 & & 74.03 & 25.97 & 47.83 \\
\hline 50 & 0.20 & 0.06 & 0.26 & & 0.32 & 0.09 & 0.41 \\
\hline$\%$ & 76.92 & 23.08 & 19.85 & & 78.05 & 21.95 & 25.47 \\
\hline 75 & 0.14 & 0.12 & 0.26 & & 0.18 & 0.09 & 0.27 \\
\hline$\%$ & 53.85 & 46.15 & 19.85 & & 66.67 & 33.33 & 16.77 \\
\hline 95 & 0.02 & 0.19 & 0.21 & & -0.17 & 0.20 & 0.03 \\
\hline$\%$ & 9.52 & 90.48 & 16.03 & & -566.66 & 666.66 & 1.86 \\
\hline \multicolumn{8}{|c|}{ Italy } \\
\hline & & & $\begin{array}{c}\text { Coeffi- } \\
\text { cients }\end{array}$ & $\begin{array}{l}\text { Charac- } \\
\text { teristics }\end{array}$ & overall & & \\
\hline & & 10 & 0.18 & 0.12 & 0.30 & & \\
\hline & & $\%$ & 60.00 & 40.00 & 40.54 & & \\
\hline & & 25 & 0.12 & 0.08 & 0.20 & & \\
\hline & & $\%$ & 60.00 & 40.00 & 27.03 & & \\
\hline & & 50 & 0.11 & 0.05 & 0.16 & & \\
\hline & & $\%$ & 68.75 & 31.25 & 21.62 & & \\
\hline & & 75 & 0.07 & 0.08 & 0.15 & & \\
\hline & & $\%$ & 46.67 & 53.33 & 20.27 & & \\
\hline & & 95 & -0.03 & 0.16 & 0.13 & & \\
\hline & & $\%$ & -23.08 & 123.08 & 17.57 & & \\
\hline
\end{tabular}


Table 5: Main Occupation of wives and husbands in 2006 with EUSILC data

\begin{tabular}{lrr}
\hline \hline Occupation & Wife & Husband \\
\hline Legislators, senior officials and managers & 0.09 & 0.23 \\
Corporate managers & 1.11 & 3.29 \\
Managers of small enterprisers & 4.62 & 5.68 \\
Physical, mathematical and engineering science professionals & 0.77 & 2.68 \\
Life science and health professionals & 1.61 & 1.59 \\
Teaching professionals & 5 & 2.32 \\
Other professionals & 1.94 & 2.41 \\
Physical and engineering science associate professionals & 0.73 & 4.16 \\
Life science and health associate professionals & 3.08 & 0.89 \\
Teaching associate professionals & 2.82 & 0.49 \\
Other associate professionals & 7.31 & 5.74 \\
Secretaries and keyboard-operating clerks & 10.76 & 5.83 \\
Customer services clerks 3 & 1.32 & \\
Personal and protective services workers & 10.81 & 4.97 \\
Models, salespersons and demonstrators & 7.04 & 2.07 \\
Skilled agricultural and fishery workers & 7.59 & 7.75 \\
Extraction and building trades workers & 0.65 & 11.74 \\
Metal, machinery and related trades workers & 0.73 & 7.82 \\
Precision, handicraft, craft printing and related trades workers & 1.41 & 1.1 \\
Other craft and related trades workers & 6.4 & 3.67 \\
Stationary-plant and related operators & 0.56 & 2.28 \\
Machine operators and assemblers & 3.94 & 3.59 \\
Drivers and mobile plant operators & 0.33 & 7.31 \\
Sales and services elementary occupations & 12.71 & 3.82 \\
Agricultural, fishery and related laborers & 3.01 & 1.74 \\
Laborers in mining, construction, manufacturing and transport & 1.91 & 3.72 \\
Armed forces & 0.08 & 1.8 \\
\hline \hline
\end{tabular}

